\title{
Consent issue dogs stem-cell approval
}

The US expansion of federal funding for human embryonic stem-cell research is being hampered by details in consent forms.

Earlier this month, researchers celebrated the government's approval of funding for a broad variety of work on 13 stem-cell lines - the first approved under the policy announced by US President Barack Obama in March.

But on 14 December, Francis Collins, director of the National Institutes of Health (NIH) in Bethesda, Maryland, decided to respect the unanimous opinion of his standing advisory committee and restrict $\mathrm{NIH}$ funding for an additional 27 lines to purposes outlined in the associated consent form. He has as yet declined to discuss his reasoning.

The forms signed by the donating couples stipulated that cells derived from the embryos "will be used to study the embryonic development of endoderm with a focus on pancreatic formation" with the longterm goal of diabetes treatment. Collins's verdict could set the tone for decisions involving some of the 80 other lines awaiting approval at the $\mathrm{NIH}$ - and another 242 lines that scientists are preparing to submit.

"This is going to be a recurring issue for the NIH: it is going to look at consent forms that either include restrictive language, or failed to include enough information about the broad array of research possibilities," says Robert Streiffer, a bioethicist at the University of Wisconsin-Madison. "Either of those situations is a problem from the perspective of informed consent."

The cell lines at issue were derived starting almost a decade ago by Doug Melton at Harvard University in Cambridge, Massachusetts. In 2005, responding to a request from Melton, Harvard's institutional "We have to take very literally what is written in that

review board freed up the lines to be used for "any legitimate scientific purpose". The cell lines had been anonymized, and the donors couldn't be traced for new consent.

But Mary Beckerle, a cancer biologist at the University of Utah in Salt Lake City, told Collins at a 4 December meeting of his advisory committee that "we have to take very literally what is written in that informed consent".

informed consent." George Daley, a stem-cell researcher at Children's

Hospital Boston in Massachusetts, says that despite the restrictions imposed on the Melton lines, federally funded researchers will get the cells they need. "Part of the advantage of having a policy that will have hundreds of new lines is that everybody should be able to find lines that are suitable for their own work," he says.

Meredith Wadman 